Check for updates

Cite this: Chem. Sci., 2019, 10, 9315

๑ All publication charges for this article have been paid for by the Royal Society of Chemistry

Received 18th June 2019

Accepted 19th August 2019

DOI: $10.1039 / \mathrm{c} 9 \mathrm{sc02990g}$

rsc.li/chemical-science

\section{Rational design of a DNA sequence-specific modular protein tag by tuning the alkylation kinetics $\uparrow$}

\author{
Thang Minh Nguyen, Eiji Nakata, (D) Zhengxiao Zhang, Masayuki Saimura, Huyen Dinh \\ and Takashi Morii $\mathbb{D}$ *
}

Sequence-selective chemical modification of DNA by synthetic ligands has been a long-standing challenge in the field of chemistry. Even when the ligand consists of a sequence-specific DNA binding domain and reactive group, sequence-selective reactions by these ligands are often accompanied by off-target reactions. A basic principle to design DNA modifiers that react at specific sites exclusively governed by DNA sequence recognition remains to be established. We have previously reported selective DNA modification by a self-ligating protein tag conjugated with a DNA-binding domain, termed as a modular adaptor, and orthogonal application of modular adaptors by relying on the chemoselectivity of the protein tag. The sequence-specific crosslinking reaction by the modular adaptor is thought to proceed in two steps: the first step involves the formation of a DNA-protein complex, while in the second step, a proximity-driven intermolecular crosslinking occurs. According to this scheme, the specific crosslinking reaction of a modular adaptor would be driven by the DNA recognition process only when the dissociation rate of the DNA complex is much higher than the rate constant for the alkylation reaction. In this study, as a proof of principle, a set of combinations for modular adaptors and their substrates were utilized to evaluate the reactions. Three types of modular adaptors consisting of a single type of selfligating tag and three types of DNA binding proteins fulfill the kinetic requirements for the reaction of the self-ligating tag with a substrate and the dissociation of the DNA-protein complex. These modular adaptors actually undergo sequence-specific crosslinking reactions exclusively driven by the recognition of a specific DNA sequence. The design principle of sequence-specific modular adaptors based on the kinetic aspects of complex formation and chemical modification is applicable for developing recognition-driven selective modifiers for proteins and other biological macromolecules.

\section{Introduction}

Site-specific chemical reactions that modify proteins and nucleic acids by ligands rely on specific molecular recognition of target sites and selective reactions. ${ }^{1}$ Sequence-selective chemical modification of DNA by DNA-binding molecules remains challenging in the field of chemistry. ${ }^{1 d, e}$ Various sequence-specific DNA binders, ranging from small molecules ${ }^{2}$ to short peptides, ${ }^{3}$ proteins, ${ }^{4}$ and synthetic oligonucleotides, ${ }^{5}$ have been coupled to a reactive group to specifically modify

Institute of Advanced Energy, Kyoto University, Uji, Kyoto 611-0011, Japan. E-mail: t-morii@iae.kyoto-u.ac.jp

$\dagger$ Electronic supplementary information (ESI) available: Rate simulation of the cross-linking reaction (Fig. S1, S2), construction of the modular adaptor (Fig. S3, S15, and Table S15), evaluation of activity and orthogonality (Table S1-S12, Fig. S4-S11), structures of DNA origami scaffolds (Fig. S12), sequence of staple strand DNAs used to assemble the DNA origami scaffold (Table S13), and statistical analyses of AFM images for determining the occupancies of DNA scaffolds by modular adaptors (Fig. S13, S14, and Table S14). See DOI: 10.1039/c9sc02990g nucleic acid bases, sugar moieties, or phosphodiester linkages. However, coupling of a reactive group to a sequence-specific DNA binding domain is often accompanied by off-target reactions. ${ }^{2-5} \mathrm{~A}$ basic principle in designing DNA modifiers exclusively governed by DNA sequence recognition has not been established.

Fully addressable nano-architectures of various shapes and geometries provide ideal scaffolds for locating molecules of interest at defined positions with a nanometer spatial precision. ${ }^{6}$ DNA scaffolds prepared by DNA origami ${ }^{7}$ can be readily incorporated with additional DNA sequences on their surface by simple extension of the staple strand. These extended DNA strands are further chemically modified to serve as binding sites for various molecules. ${ }^{8}$ Proteins are a particularly interesting class of molecules for assembly on the DNA scaffold because of their wide functional variability. ${ }^{9}$ For assembly on the DNA scaffold through hybridization, a protein of interest (POI) is chemically modified with a short DNA strand that is complementary to the attached sequence on the DNA scaffold. ${ }^{10}$ Although this method is convenient, it has some limitations; for 
example, the modification conditions are limited and may cause loss of activity. ${ }^{\mathbf{1 1 , 1 2}}$ It would be ideal to locate the POI at a specific position on the DNA scaffold without the requirement for post-chemical modification of the POI to prepare a precisely controlled assembly suitable for further investigation. ${ }^{9 c, 13}$ To achieve efficient and rapid placement of a POI at a specific DNA site, we developed modular adaptors (Fig. 1a and b). ${ }^{\mathbf{1 4 1 5}} \mathrm{A}$ modular adaptor consists of a DNA-binding protein (zif268 ${ }^{16}$ ) that functions as a DNA sequence-selective recognition module and self-ligating protein tag (SNAP-tag ${ }^{17}$ ) which forms a chemoselective covalent linkage between the protein tag and its substrate $O^{2}$-benzylguanine (BG) modified at the given DNA sequence (Fig. 1a). ${ }^{14}$ A modular adaptor-fused enzyme was specifically located at the target position of the DNA scaffold with fast reaction kinetics and in high yield while fully retaining the original enzymatic activity. ${ }^{\mathbf{1 8}}$ In order to assemble three types of proteins at unique positions on the DNA scaffold, a set of modular adaptors with orthogonality and which retained fast reaction kinetics under mild conditions was selected from the systematic combination of DNA-binding domains (zif268 or AZP4 ${ }^{19}$ ) and protein tags, SNAP-tag, CLIP-tag, ${ }^{20}$ and Halotag. ${ }^{15,21}$ Among them, three types of orthogonal modular adaptors simultaneously directed the three types of proteins to their respective positions on the DNA scaffold. In a previous study, orthogonal cross-linking reactions of modular adaptors were mainly conducted by taking advantage of the chemoselective characteristics of self-ligating protein tags (Fig. 1c), not exclusively by the sequence selectivity of the DNA-binding protein. In fact, zif268 conjugated with SNAP-tag (ZF-SNAP) and AZP4 conjugated with SNAP-tag (AZ-SNAP) reacted to the same extent with BG at both the zif268 and AZP4 binding sequences. ${ }^{15}$ This non-sequence-selective modification was discussed by considering the kinetics of the sequence-specific crosslinking reaction by the modular adaptor in two steps: the first step is the formation of a DNA-protein complex, and a proximity-driven intermolecular crosslinking reaction is initiated in the second step (Fig. 1b). According to this scheme, the specific crosslinking reaction of a modular adaptor would be driven by the DNA recognition process only when the dissociation rate of the DNA complex is much higher than the rate constant for the alkylation reaction.

In this study, as a proof of principle for the above concept, we constructed sequence-selective modular adaptors by tuning the reaction kinetics between the self-ligating protein tag and its substrate (Fig. 2a and d). Conjugation of different types of DNAbinding domains to the same self-ligating protein tag provides a variety of orthogonal modular adaptors, in which the a

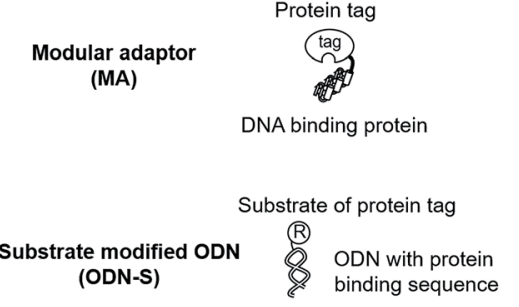

c Orthogonality driven by chemo-selectivity (Previous study)

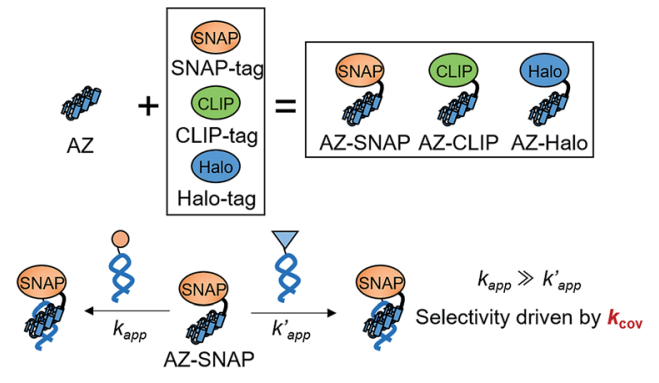

b

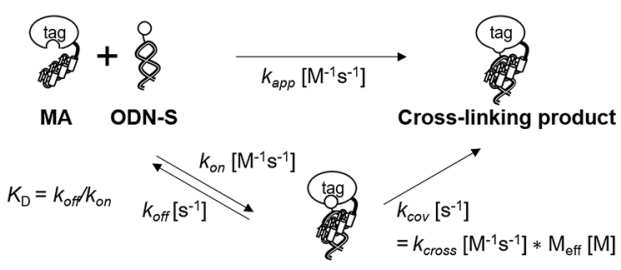

complex
(1)

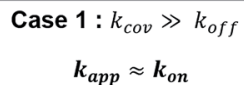

$\boldsymbol{k}_{\text {app }} \approx \boldsymbol{k}_{\text {on }}$

$\boldsymbol{k}_{a p p} \approx \frac{\boldsymbol{k}_{c o v}}{\boldsymbol{K}_{D}}$

d Orthogonality driven by sequence selectivity (This study)

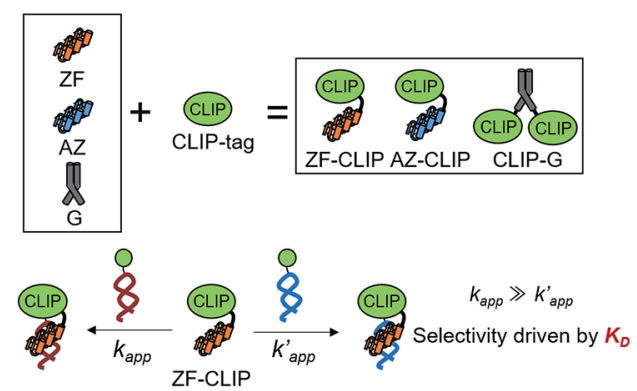

Fig. 1 (a) Structures and elements of the modular adaptor (MA) and substrate-modified oligodeoxyribonucleotide (ODN-S). (b) Scheme of the cross-linking reaction between MA and ODN-S. Complex formation between MA and ODN-S is governed by the equilibrium dissociation constant $\left(K_{\mathrm{D}}\right)[\mathrm{M}]$ as defined by $K_{\mathrm{D}}=k_{\mathrm{off}} / k_{\mathrm{on}}$. The apparent rate constant $\left(k_{\mathrm{app}}\right)\left[\mathrm{M}^{-1} \mathrm{~s}^{-1}\right]$ is expressed as $k_{\mathrm{on}}$ and $k_{\mathrm{off}}$ (or $\left.K_{\mathrm{D}}\right)$ and the rate constant $k_{\mathrm{cov}}\left[\mathrm{s}^{-1}\right]$ for the proximity-driven intermolecular crosslinking reaction between MA and ODN-S is defined by the rate constant of intermolecular covalent formation $\left(k_{\text {cross }}\right)\left[\mathrm{M}^{-1} \mathrm{~s}^{-1}\right.$ ] and the effective concentration $\left(M_{\text {eff }}\right)[\mathrm{M}]$ (eqn (1)). (c) Orthogonal cross-linking reactions driven by the chemo-selectivity of the protein tag described in our previous study. ${ }^{15}$ The apparent reaction rate constants for the matched pair and the unmatched pair are indicated as $k_{\text {app }}\left[\mathrm{M}^{-1} \mathrm{~s}^{-1}\right]$ and $k_{\mathrm{app}}^{\prime}\left[\mathrm{M}^{-1} \mathrm{~s}^{-1}\right]$, respectively. The selective cross-linking reaction proceeds when $k_{\mathrm{app}} \gg k_{\mathrm{app}}^{\prime}$, which is realized only when $k_{\text {cov }}$ for the matched pair of the substrate of protein tags is much larger than that for the unmatched pair of the substrate of protein tags. (d) Orthogonal cross-linking reactions driven by the sequence selectivity of DNA-binding domains and chemoselective cross-linking reactions by the protein tag described in this study. The selective reactions of ZF-CLIP, AZ-CLIP, and CLIP-G proceed with $k_{\text {app }}$ in case 2 of (b) with selectivity mainly governed by $K_{\mathrm{D}}$. 
a

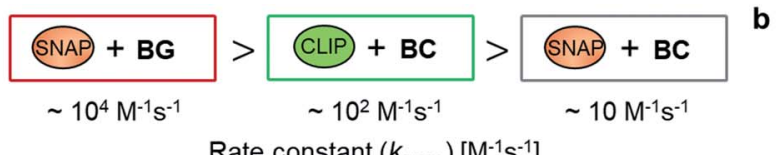

Rate constant $\left(k_{\text {cross }}\right)\left[\mathrm{M}^{-1} \mathrm{~s}^{-1}\right]$
Candidates of modular adaptor
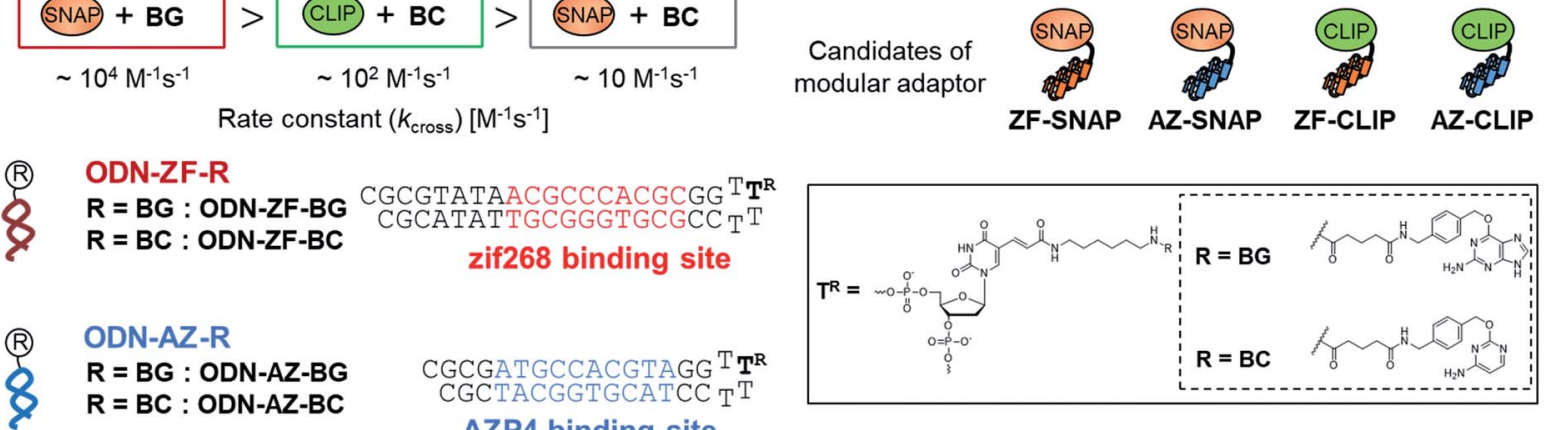
CGCGATGCCACGTAGG ${ }^{\mathrm{T}} \mathbf{T}^{\mathrm{R}}$ AZP4 binding site

d
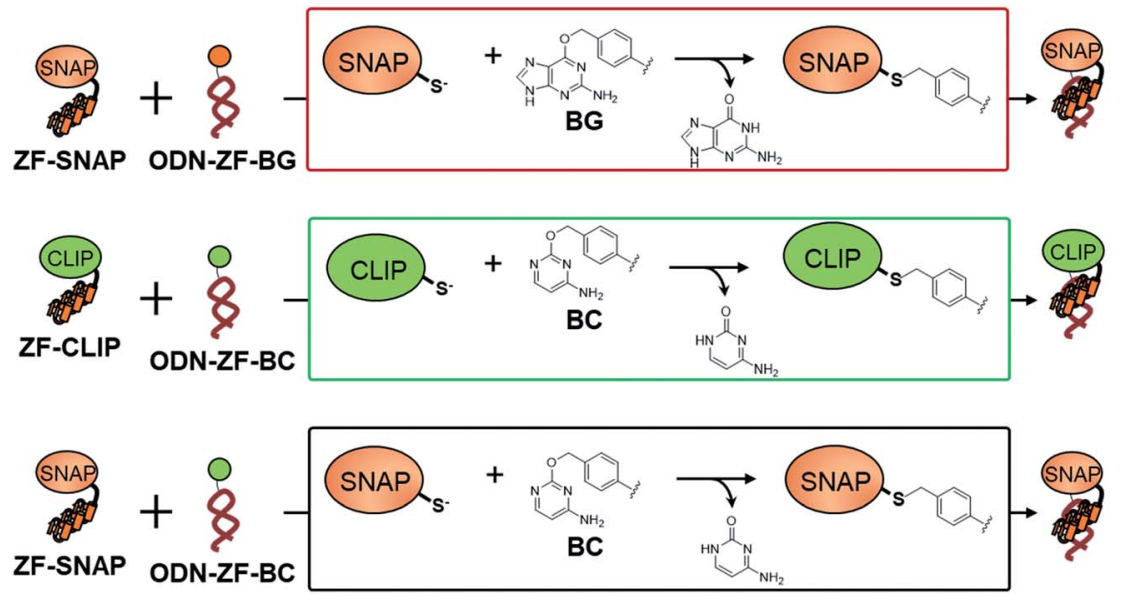

Fig. 2 (a) Comparison of the reactivity of the combination of the protein tag and substrate $\left(k_{\text {cross }}\right)$. (b) Candidates for the modular adaptor used in this study. (c) Nucleotide sequences of ODNs for each modular adaptor with the substrate for protein tags and chemical structures of the substrates for protein tag-modified $T$, denoted as " $\mathrm{T}^{\mathrm{R}}$ ". (d) Reaction schemes representing the cross-linking reactions between the modular adaptors (ZF-SNAP or ZF-CLIP) and substrates incorporated into ODN-S (ODN-ZF-BG and ODN-ZF-BC).

crosslinking reaction is exclusively governed by sequencespecific DNA recognition (Fig. 1d).

The reaction of the modular adaptor with its substrate at the specific DNA sequence proceeds through specific recognition of the DNA sequence and an alkylation reaction between the protein tag and its substrate (Fig. 1b). Therefore, the factors governing the specific reactions of modular adaptors are wellcorrelated with the design of selective DNA modifiers driven by sequence-specific DNA recognition. ${ }^{18,22}$ Our design principle of modular adaptors based on the kinetic parameters of the DNA binding and alkylation reaction would be applicable to design a wide range of site-specific modifiers driven by target recognition.

\section{Results}

Kinetic aspects of the modular adaptor provide a design strategy for sequence-specific modular adaptors for orthogonal covalent bond formation with the substratemodified ODNs

Our previous study of the reaction of modular adaptors, consisting of a DNA-binding domain and a cross-link forming protein tag (Fig. 1a), suggested important factors that affected the kinetics and selectivity of the cross-linking reaction.
Covalent bond formation between the modular adaptor and its substrate-modified oligodeoxyribonucleotide (ODN-S) (Fig. 1a) occurs in the following two steps (Fig. 1b): a reversible complex forms between the DNA-binding domain and ODN-S, and then a proximity-driven intermolecular cross-linking reaction occurs between the self-ligating protein tag domain and its substrate on ODN-S. ${ }^{15}$ The apparent rate constant of the cross-linking reaction $\left(k_{\text {app }}\right)\left(\mathrm{M}^{-1} \mathrm{~s}^{-1}\right)$ between the modular adaptor and substrate-modified DNA is represented by eqn (1) shown in Fig. 1b. In eqn (1), a modular adaptor with a highly reactive protein tag to its substrate $\left(k_{\text {cov }} \gg k_{\text {off }}\right)$ falls into case $1 .^{23,24}$ Because the association rates $\left(k_{\mathrm{on}}\right)$ of DNA-binding proteins to their specific and non-specific sites are nearly identical, ${ }^{24}$ the modular adaptor is thought to react with ODN-S regardless of the DNA sequence (case 1 in Fig. 1b). Therefore, reducing the reactivity of the protein tag with the substrate $\left(k_{\text {cov }}\right)$ to fit into the condition of case $2, k_{\text {cov }} \ll k_{\text {off }}$ (Fig. 1b), would be an effective strategy for preventing the cross-linking reaction at unmatched DNA sequences by modular adaptors. In case 2 , a higher equilibrium dissociation constant $\left(K_{\mathrm{D}}\right)$ for the unmatched complex of the zinc finger motif and ODNs results in fewer cross-linking reactions of unmatched complexes. The difference in the cross-linking reactions for the matched and 
unmatched pairs evaluated in our previous study ${ }^{\mathbf{1 5}}$ and this study is described in Fig. 1c and d, respectively.

Time-dependent changes in the yield of the cross-linking reaction (Fig. S1 $\dagger$ ) were simulated by varying the apparent rate constants. In addition, the apparent reaction rate constant of the matched pair $\left(k_{\mathrm{app}}\right)$ and that of the unmatched pair $\left(k_{\mathrm{app}}^{\prime}\right)$ were investigated with various $k_{\text {cov }}$ values (Fig. S2 $\dagger$ ). From these simulations, the sequence-selective orthogonal cross-linking reaction takes place when the rate constant of the matched pair $\left(k_{\text {app }}\right)$ is two orders of magnitude higher than that of the unmatched pair $\left(k_{\text {app }}^{\prime}\right)$. Thus, to achieve the sequence-selective crosslinking reaction, the reactivity of the cross-linking reaction should be finely tuned to meet the condition of case 2 .

To test the above hypothesis, three combinations of protein tags and substrates, SNAP-tag with BG $\left(\sim 10^{4} \mathrm{M}^{-1} \mathrm{~s}^{-1}\right),{ }^{17,20}$ CLIPtag with $O^{2}$-benzylcytosine (BC) $\left(\sim 10^{2} \mathrm{M}^{-1} \mathrm{~s}^{-1}\right),{ }^{20}$ and SNAP-tag with $\mathrm{BC}\left(\sim 10 \mathrm{M}^{-1} \mathrm{~S}^{-1}\right),{ }^{20}$ were prepared for the cross-linkforming domain of the modular adaptor (Fig. 2a). Two DNA binding proteins, zif268 (ZF) and AZP4 (AZ), were utilized as the DNA-binding domain of the modular adaptor (Fig. 2b). ZF-CLIP was constructed by fusing CLIP-tag to the C-terminus of zif268 through a GGSGGS linker (Fig. S3a $\dagger$ ). ZF-SNAP, AZ-SNAP, and AZ-CLIP were prepared as described previously. ${ }^{15}$ ODNs containing the zif268- or AZP4-binding sequence were designed to form a loop with four $\mathrm{T}$ nucleotides, in which one of the $\mathrm{T}$ nucleotides was replaced with amino-C6-T (ODN-ZF or ODN$\mathrm{AZ}$ ). Amino-C6-T was modified with each of the substrates, BG or BC (ODN-ZF-BG, ODN-ZF-BC, ODN-AZ-BG or ODN-AZ-BC, respectively, as shown in Fig. 2c). Complex formations by $\mathrm{ZF}$ or $\mathrm{AZ}$ derivatives and ODN-ZF or ODN-AZ were titrated by means of fluorescence polarization measurements to determine the $K_{\mathrm{D}}$ values (Fig. S4 and Table S1, S2 $\dagger$ ). The results confirmed that the $K_{\mathrm{D}}$ values for the matched and unmatched complexes differed by more than two orders of magnitude. Cross-linking reactions of these modular adaptors with ODN-S containing the respective matched or unmatched sequence were analysed by denaturing polyacrylamide gel electrophoresis (PAGE) as shown in Fig. 3. In the combination of SNAP-tag and $\mathrm{BG}, k_{\text {app }}$ values for the reactions of the matched pair ZF-SNAP with ODN-ZF-BG and AZ-SNAP with ODN-AZ-BG were $3.8 \times 10^{5}$ and $9.1 \times 10^{5} \mathrm{M}^{-1}$ $\mathrm{S}^{-1}$, respectively (Table 1 ). For the combination of CLIP-tag and $\mathrm{BC}, k_{\mathrm{app}}$ values for the reactions of the matched pair ZF-CLIP with ODN-ZF-BC and AZ-CLIP with ODN-AZ-BC were $7.1 \times 10^{5}$ and $5.0 \times 10^{5} \mathrm{M}^{-1} \mathrm{~s}^{-1}$, respectively (Table 1 ). In the combination of SNAP-tag with $\mathrm{BC}, k_{\mathrm{app}}$ values for the reactions of the matched pair ZF-SNAP with ODN-ZF-BC and AZ-SNAP with ODN-AZ-BC were $1.7 \times 10^{3}$ and $3.0 \times 10^{2} \mathrm{M}^{-1} \mathrm{~s}^{-1}$, respectively (Table 1). The cross-linking reactions between ZF-SNAP and ODN-ZF-BG, AZ-SNAP and ODN-AZ-BG, ZF-CLIP and ODN-ZFBC, and AZ-CLIP and ODN-AZ-BC gave yields of 94\%, 93\%, $92 \%$, and $90 \%$, respectively (Fig. $3 \mathrm{a}$ and $\mathrm{b}$ ). The reactions of ZFSNAP with ODN-ZF-BC and AZ-SNAP with ODN-AZ-BC were very slow and showed yields of $40 \%$ and $46 \%$, respectively, after $30 \mathrm{~min}$ of incubation under the described conditions (Fig. 3c).

Next, we evaluated the reactions of unmatched pairs for each combination of the protein tag and substrate (Table 1). The $k_{\text {app }}^{\prime}$ values of the unmatched pairs of ZF-SNAP with ODN-AZ-BG and
AZ-SNAP with ODN-ZF-BG were $2.6 \times 10^{4}$ and $9.5 \times 10^{4} \mathrm{M}^{-1} \mathrm{~s}^{-1}$, respectively. The $k_{\text {app }}^{\prime}$ values of the unmatched pairs of ZF-CLIP with ODN-AZ-BC and AZ-CLIP with ODN-ZF-BC were $2.8 \times 10^{3}$ and $8.1 \times 10^{2} \mathrm{M}^{-1} \mathrm{~s}^{-1}$, respectively. The $k_{\text {app }}^{\prime}$ values of the unmatched pairs of ZF-SNAP with ODN-AZ-BC and AZ-SNAP with ODN-ZF-BC were 22 and $11 \mathrm{M}^{-1} \mathrm{~s}^{-1}$, respectively (Table 1). The $k_{\text {app }}^{\prime}$ values of unmatched pairs of ZF-SNAP and AZ-SNAP were one to two orders of magnitude lower than the $k_{\text {app }}$ of the matched pairs. Thus, the sequence-specific reaction only minimally occurred, as shown in Fig. S1. $\dagger$ In contrast, the $k_{\text {app }}^{\prime}$ values of ZF-CLIP and AZ-CLIP were two orders of magnitude lower than $k_{\text {app }}$ of the matched pairs (Fig. S5 $\dagger$ and Table 1). In the combination of CLIP-tag and $\mathrm{BC}$, the observed differences in the apparent second-order rate constants were parallel to the difference in the equilibrium dissociation constants for the matched and unmatched complexes of ZF-CLIP and AZ-CLIP, as expected from eqn (1) in case 2 (Fig. 1b). These results indicated that the cross-linking reaction of the modular adaptors consisting of CLIP-tag with the substrate BC on ODNs proceeded as shown in case 2 of eqn (1). Because the larger $k_{\text {app }}$ for the matched pair was preferred as long as it falls within case 2, the pair of CLIP-tag and $\mathrm{BC}$ was selected as the self-ligating protein tag domain for modular adaptors that would form a covalent linkage at a specific sequence driven by the DNA recognition domain.

\section{Sequence-specific reactions of modular adaptors consisting of CLIP-tag with BC modified ODNs}

Three types of modular adaptors bearing the same self-ligating protein tag but different DNA-binding domains (ZF-CLIP, AZCLIP, and CLIP-G) were tested in a sequence-selective crosslinking reaction with ODNs modified with BC (Fig. 4). CLIP-G consisted of a basic-leucine zipper (bZIP) class of protein GCN4 ${ }^{25}$ as a homo-dimeric DNA binding module and CLIP-tag fused to the N-terminus of GCN4 through a GGSGGS linker. An ODN containing the AP1 sequence as the GCN4 binding site was designed for the matched target for CLIP-G, in which two $\mathrm{T}$ nucleotides at either ends of the AP1 sequence were displaced by amino-C6-T (ODN-AP). ODN-AP was further modified with BC (ODN-AP-2BC) as the substrate of CLIP-G (Fig. S3b and $\mathrm{c}^{\dagger}$ ). The cross-linking reactions of ZF-CLIP, AZ-CLIP, and CLIP-G with their respective matched ODNs were nearly orthogonal, as shown in Fig. 4c, with more than $90 \%$ yield for matched pairs and less than $19 \%$ covalent bond formation for unmatched pairs. The observed sequence-specific cross-linking reactions of ZF-CLIP, AZ-CLIP, and CLIP-G were driven by the specific DNA binding of each modular adaptor (Fig. S5, Table S3 $\dagger$ ). The $k_{\text {app }}$ for the reaction of CLIP-G and its matched sequence ODN-AP2BC was determined to be $2.1 \times 10^{6} \mathrm{M}^{-1} \mathrm{~s}^{-1}$ and $k_{\text {app }}^{\prime}$ values ranged from $10^{3}$ to $10^{4} \mathrm{M}^{-1} \mathrm{~s}^{-1}$. For the reactions of unmatched pairs, ZF-CLIP or AZ-CLIP with ODN-AP-2BC, the $k_{\text {app }}^{\prime}$ values were $10^{2}-10^{3} \mathrm{M}^{-1} \mathrm{~s}^{-1}$. Furthermore, in the presence of $200 \mathrm{mM}$ $\mathrm{NaCl}$, non-specific DNA binding was reduced (Fig. S6 and Table $\mathrm{S} 4 \dagger)^{26,27}$ and covalent bond formation at the unmatched pairs were further reduced to less than $5 \%$ (Fig. $4 \mathrm{~d}$ ). The yields of the matched pairs were also reduced for AZ-CLIP (64\%) and ZFCLIP $(88 \%)$. The kinetic constants of the matched and 
a

MA

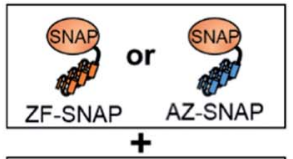

ODN-S

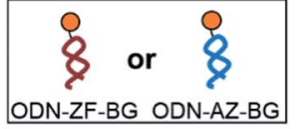

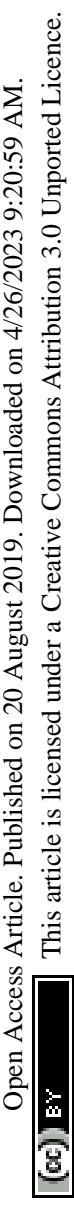

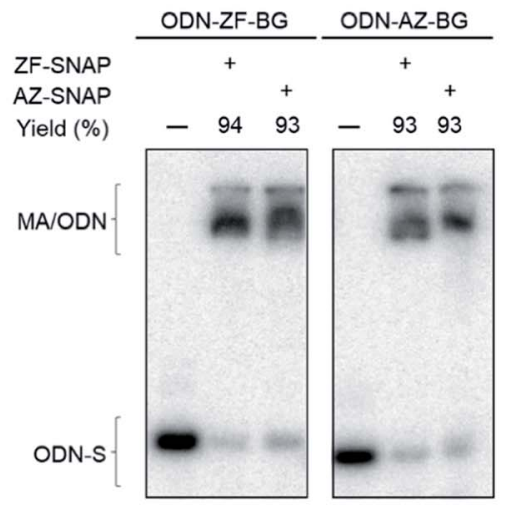

d

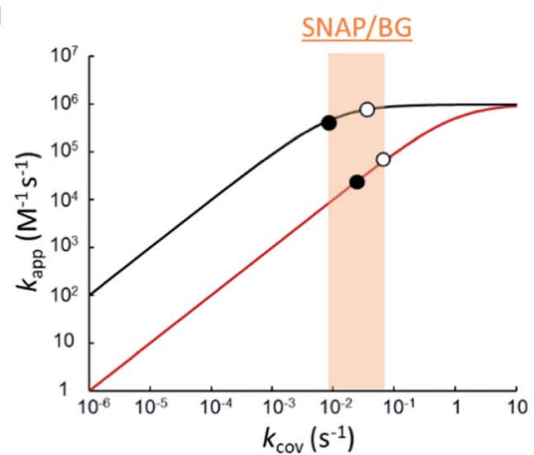

b
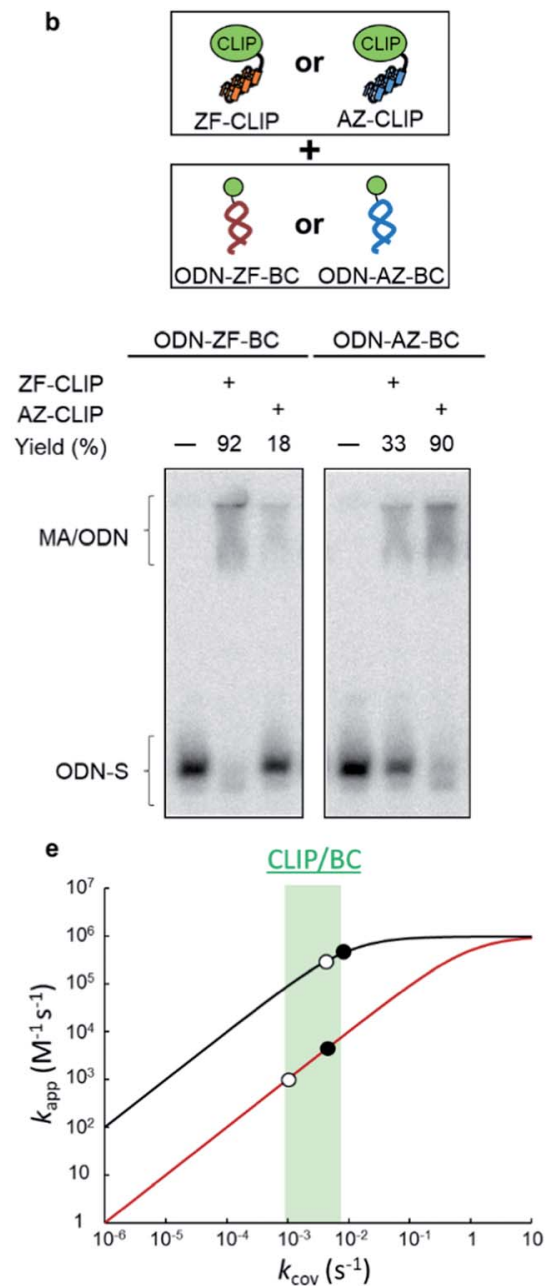

c
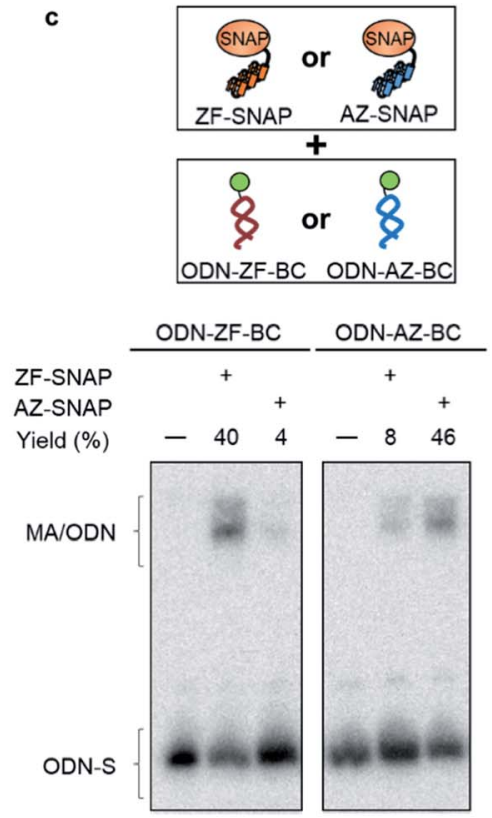

f

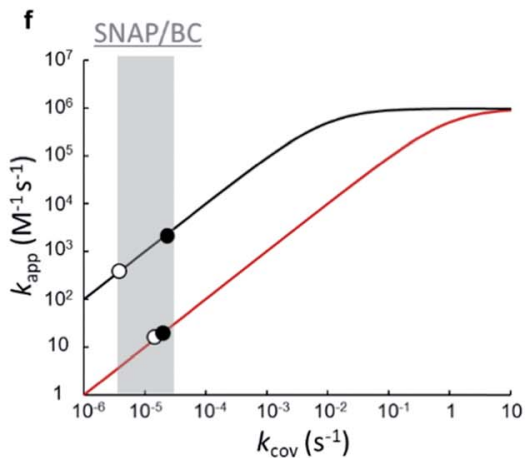

Fig. 3 Analyses of cross-linking reactions between the modular adaptors and the substrate-modified ODNs. (a-c) Denaturing PAGE analyses of the cross-linking reaction by modular adaptors (MA: ZF-SNAP, AZ-SNAP, ZF-CLIP and AZ-CLIP) and each ODN-S (ODN-ZF-BG, ODN-AZ-BG, ODN-ZF-BC and ODN-AZ-BC). Each 5'-32 P-end-labeled ODN-S was incubated with a modular adaptor (100 nM) for $30 \mathrm{~min}$ in a buffer (pH 8.0 ) containing $40 \mathrm{mM}$ Tris- $\mathrm{HCl}, 20 \mathrm{mM}$ acetic acid, $12.5 \mathrm{mM} \mathrm{MgCl}, 1 \mathrm{mM} \mathrm{DTT}, 1 \mu \mathrm{M} \mathrm{ZnCl}_{2}, 0.02 \%$ Tween 20, 200 nM BSA and 100 nM calf thymus DNA at ambient temperature. (d-f) Simulation of $k_{\mathrm{app}}$ with various $k_{\mathrm{cov}}$ by following eqn (1) (Fig. 1b). The $k_{\mathrm{app}}$ values for the matched and unmatched pairs of MA and ODN-S at given $k_{\text {cov }}$ are shown in black and red curves, respectively. The details of simulation conditions are shown in Fig. S2. $\uparrow$ The experimentally obtained $k_{\text {app }}$ values (Table 1 ) are marked on the simulated lines. Filled and open circles indicate MA conjugated with ZF and AZ, respectively. (d) Reactions of SNAP-tag conjugated MAs with BG. (e) Reactions of CLIP-tag conjugated MAs with BC. (f) Reactions of SNAP-tag conjugated MAs with BC.

Table 1 Kinetic parameters ( $k_{\mathrm{app}}$ or $k_{\mathrm{app}}^{\prime}$ ) for the cross-linking reactions between ODN-S and MAs

\begin{tabular}{|c|c|c|c|}
\hline & $k_{\text {app }}\left(\mathrm{M}^{-1} \mathrm{~s}^{-1}\right)$ & $k_{\mathrm{app}}^{\prime}\left(\mathbf{M}^{-1} \mathrm{~s}^{-1}\right)$ & \\
\hline MAs & (ODN-S) & (ODN-S) & $k_{\text {app }} / k_{\text {app }}^{\prime}$ \\
\hline ZF-SNAP & $\begin{array}{l}(3.8 \pm 1.2) \times 10^{5} \\
(\text { ODN-ZF-BG })\end{array}$ & $\begin{array}{l}(2.6 \pm 0.2) \times 10^{4} \\
(\text { ODN-AZ-BG })\end{array}$ & 15 \\
\hline AZ-SNAP & $\begin{array}{l}(9.1 \pm 2.4) \times 10^{5} \\
(\mathrm{ODN}-\mathrm{AZ}-\mathrm{BG})\end{array}$ & $\begin{array}{l}(9.5 \pm 0.6) \times 10^{4} \\
(\text { ODN-ZF-BG })\end{array}$ & 10 \\
\hline ZF-CLIP & $\begin{array}{l}(7.1 \pm 0.2) \times 10^{5} \\
(\text { ODN-ZF-BC) }\end{array}$ & $\begin{array}{l}(2.8 \pm 0.2) \times 10^{3} \\
(\mathrm{ODN}-\mathrm{AZ}-\mathrm{BC})\end{array}$ & 254 \\
\hline AZ-CLIP & $\begin{array}{l}(5.0 \pm 0.7) \times 10^{5} \\
(\mathrm{ODN}-\mathrm{AZ}-\mathrm{BC})\end{array}$ & $\begin{array}{l}(8.1 \pm 2.7) \times 10^{2} \\
(\mathrm{ODN}-\mathrm{ZF}-\mathrm{BC})\end{array}$ & 617 \\
\hline ZF-SNAP & $\begin{array}{l}(1.7 \pm 0.2) \times 10^{3} \\
(\text { ODN-ZF-BC })\end{array}$ & $\begin{array}{l}22 \pm 1 \\
\text { (ODN-AZ-BC) }\end{array}$ & 77 \\
\hline AZ-SNAP & $\begin{array}{l}(3.0 \pm 0.1) \times 10^{2} \\
(\text { ODN-AZ-BC })\end{array}$ & $\begin{array}{l}11 \pm 3 \\
(\mathrm{ODN}-\mathrm{ZF}-\mathrm{BC})\end{array}$ & 27 \\
\hline
\end{tabular}

unmatched pairs for SNAP-tag and CLIP-tag in the presence of $200 \mathrm{mM} \mathrm{NaCl}$ are summarized in Fig. S7 and Tables S5 and S6, $\dagger$ respectively. Under this condition, the sequence-specificity of ZF-CLIP to the consensus sequence of zif268 (GCGTGGGCGT) and its mutated sequences was further investigated (Table $\mathrm{S} 7 \dagger$ ). $\mathrm{ODN}-\mathrm{ZF}(\mathrm{G} / \mathrm{T})$ and $\mathrm{ODN}-\mathrm{ZF}(\mathrm{G} / \mathrm{C})$ contained a single nucleotide substitution in the consensus sequence and ODN-ZF(GG/TC) and ODN-ZF(GC/CT) were mutated with two nucleotides. The $K_{\mathrm{D}}$ values reported for the complexes of zif268 and these sequences were more than one order of magnitude higher than those with the consensus sequence. ${ }^{24}$ Actually, the $K_{\mathrm{D}}$ values determined for the binding complexes of ZF-CLIP and these mutated ODNs by means of a fluorescence polarization assay were more than one order of magnitude higher for single nucleotide substituted ODN-ZF(G/T) and ODN-ZF(G/C) and two 


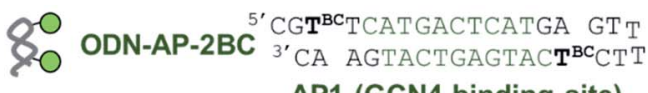

b

MA (CLIP derivatives) or

AP1 (GCN4 binding site)

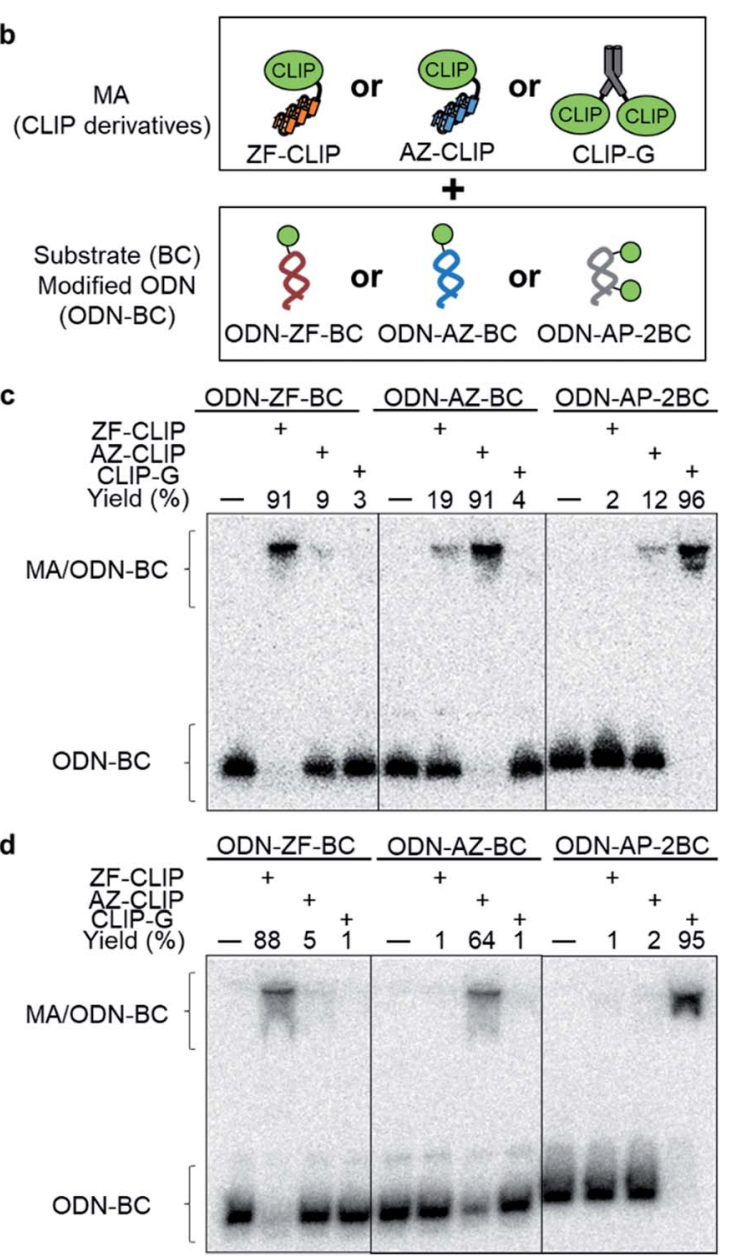

Fig. 4 (a) Nucleotide sequences of ODNs for GCN4 with BC modified $\mathrm{T}$, denoted as " $\mathrm{T}^{\mathrm{BC}}$ " (ODN-AP-2BC). (b) Illustrations of the optimized sequence-specific modular adaptors (MAs) and substrate-modified ODN (ODN-S). (c and d) Autoradiograms show denaturing PAGE analyses of the crosslinking reaction of MA (ZF-CLIP, AZ-CLIP, and CLIP-G) and ODN-S (ODN-ZF-BC, ODN-AZ-BC, and ODN-AP-2BC) with (c) or without $200 \mathrm{mM} \mathrm{NaCl}$ (d). Each $5^{\prime}-{ }^{32}$ P-end-labeled ODN-S

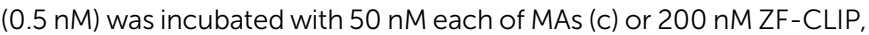
$500 \mathrm{nM} \mathrm{AZ-CLIP}$, or $100 \mathrm{nM}$ CLIP-G (d), respectively, for $10 \mathrm{~min}$ (c) and $60 \mathrm{~min}(\mathrm{~d})$. These reactions were carried out in a buffer $(\mathrm{pH} 8.0)$ containing $40 \mathrm{mM}$ Tris $-\mathrm{HCl}, 20 \mathrm{mM}$ acetic acid, $12.5 \mathrm{mM} \mathrm{MgCl}, 1 \mathrm{mM}$ $\mathrm{DTT}, 1 \mu \mathrm{M} \mathrm{ZnCl}$, and $200 \mathrm{mM} \mathrm{NaCl}$ in (d), and $0.02 \%$ Tween 20 at ambient temperature.

orders of magnitude higher for two nucleotide substituted ODN$\mathrm{ZF}(\mathrm{GG} / \mathrm{TC})$ and ODN-ZF(GC/CT) than that for ODN-ZF (Fig. S8 and Table $\mathrm{S} 8 \dagger$ ), being consistent with previous studies. ${ }^{24}$ The $k_{\text {app }}$ for the reaction of ZF-CLIP and ODN-ZF-BC in the presence of $200 \mathrm{mM} \mathrm{NaCl}$ was determined to be $5.1 \times 10^{4} \mathrm{M}^{-1} \mathrm{~s}^{-1}$. For the reaction with these mutated ODNs, the $k_{\text {app }}^{\prime}$ values for the single nucleotide substituted ODN-ZF(G/T) and ODN-ZF(G/C) were 1.6 $\times 10^{3}$ and $2.3 \times 10^{3} \mathrm{M}^{-1} \mathrm{~s}^{-1}$, respectively (Fig. S9 and Table S9†). The $k_{\text {app }}^{\prime}$ for the two nucleotide substituted ODNs ODN-ZF(GG/ a
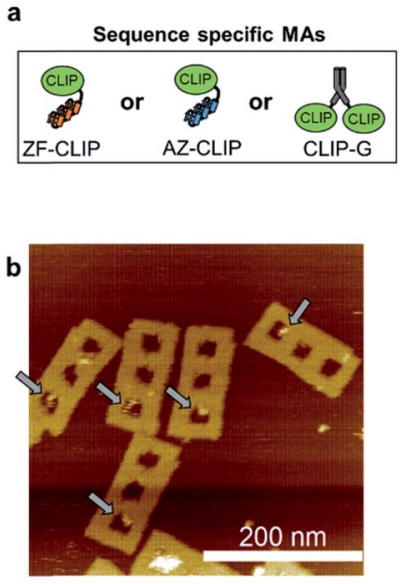

Matched position: $92 \%$ Unmatched position: $7 \%$

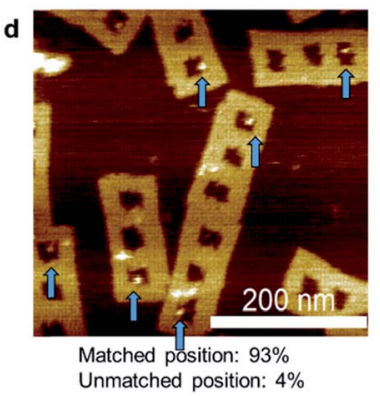

DNA origami scaffold (I-1CG/II-1ZC/III-1AC)

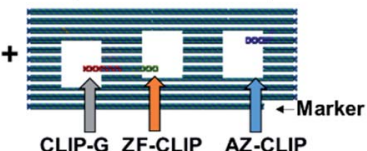

CLIP-G ZF-CLIP AZ-CLIP Specific binding site

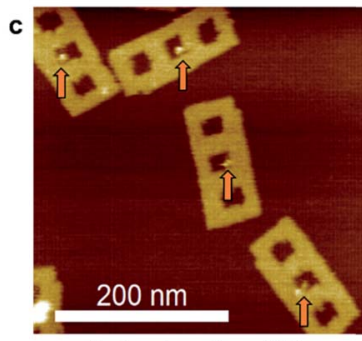

Matched position: $90 \%$ Unmatched position: $4 \%$

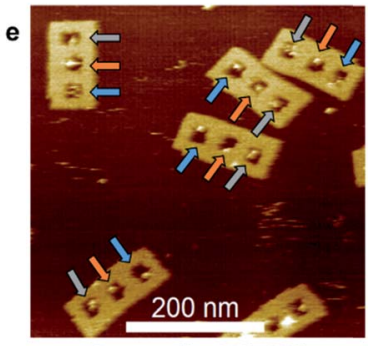

Coassembly yield: $87 \%$

Fig. 5 Three types of sequence-specific MAs orthogonally reacted at the predesigned positions on the DNA scaffold. (a) Three types of MAs and the DNA origami scaffold (I-1CG/II-1ZC/III-1AC). The DNA origami scaffold (I-1CG/II-1ZC/III-1AC), in which each cavity contained a single site for one MA. The stem loops in red, green, and blue denote the binding sites for CLIP-G (CG) in cavity I, ZF-CLIP (ZC) in cavity II, and AZ-CLIP (AC) in cavity III, respectively. (b-e) AFM images of the DNA scaffold reacted with MAs. (b-d) The DNA scaffold (5 nM) was incubated with MAs (250 nM) (b) CLIP-G, (c) ZF-CLIP, or (d) AZ-CLIP for $30 \mathrm{~min}$ at ambient temperature. (e) One-pot coassembly reaction of three MAs on the DNA scaffold (I-1CG/II-1ZC/III-1AC). The DNA scaffold $(5 \mathrm{nM})$ was incubated with CLIP-G, ZF-CLIP and AZ-CLIP (250 $\mathrm{nM}$ each) for $30 \mathrm{~min}$ at ambient temperature. These reactions were carried out in a buffer $(\mathrm{pH} 8.0)$ containing $40 \mathrm{mM}$ Tris $-\mathrm{HCl}$, $20 \mathrm{mM}$ acetic acid, $12.5 \mathrm{mM} \mathrm{MgCl} 2,200 \mathrm{mM} \mathrm{NaCl}, 1 \mathrm{mM}$ DTT, $1 \mu \mathrm{M}$ $\mathrm{ZnCl}_{2}$, and $0.02 \%$ Tween 20 . The reaction mixture was purified by sizeexclusion chromatography and then analysed by atomic force microscopy (AFM). Yields at each cavity and coassembly yields were estimated by counting the number of cavities occupied by the modular adaptors (Table S14†).

TC) and ODN-ZF(GC/CT) could not be obtained because of their very slow reactions. These results clearly demonstrated that the sequence selective cross-linking reaction of the modular adaptor consisting of CLIP-tag with the substrate BC on ODNs proceeded by discriminating single nucleotide substitution, and indicated that the selectivity of the crosslinking reaction was governed by the $K_{\mathrm{D}}$ of the binding complex.

\section{Coassembly of modular adaptors on a DNA scaffold}

Three modular adaptors, ZF-CLIP, AZ-CLIP, and CLIP-G, were reacted at the designed positions on the DNA scaffold. 
Rectangular DNA scaffold (Fig. 5a and S12 $\dagger$ ) containing three cavities was prepared as described previously. ${ }^{18}$ Each modular adaptor $(250 \mathrm{nM})$ was incubated with $5 \mathrm{nM}$ of the DNA scaffold (I-1CG/II-1ZC/III-1AC) containing a single binding site for CLIPG, ZF-CLIP, and AZ-CLIP at cavity I, II, and III, respectively, in a buffer containing $200 \mathrm{mM} \mathrm{NaCl}$ (Fig. 5 and $\mathrm{S} 13 \dagger$ ). The reaction at the matched positions achieved over $90 \%$ yield in $30 \mathrm{~min}$ with less than 7\% modifications at unmatched positions (Fig. 5b-d). Sequential reactions in the presence of $200 \mathrm{mM} \mathrm{NaCl}$ in the order of CLIP-G, AZ-CLIP, and ZF-CLIP confirmed that modification had occurred at the unmatched positions (less than $10 \%$ in total), as shown in Fig. S14. $\dagger$ The one pot co-assembly reaction of the modular adaptors for their respective target positions on the DNA scaffold (Fig. 5e) resulted in $87 \%$ coassembly yield after $30 \mathrm{~min}$ of incubation.

\section{Discussion}

Based on eqn (1) of $k_{\text {app }}$ in Fig. 1b, the factors affecting the kinetics and selectivity of the cross-linking reaction are the reactivity of the self-ligating protein tag $\left(k_{\text {cov }}\right)$ and the recognition process of the DNA binding domain $\left(k_{\text {on }}, k_{\text {off }}\right.$, or $\left.K_{\mathrm{D}}\right)$. In our previous study, orthogonal cross-linking reactions of modular adaptors were mainly conducted by taking advantage of the chemoselectivity of protein tags (Fig. 1c). ${ }^{15}$ Thus, the selective reactions were driven by differences in the $k_{\text {cov }}$ of the reaction. Although this strategy was effective for the orthogonal crosslinking reactions, only a few variations in the orthogonal modular adaptors were available because the number of effective pairs of protein tags and substrates was limited. In contrast, DNA-binding proteins show a wide range of sequence selectivity and affinity for the recognition modules of modular adaptors. ${ }^{28}$ In case 2 of eqn (1), where $k_{\text {cov }} \ll k_{\text {off }}$, the difference in $K_{\mathrm{D}}$ values of the matched and unmatched DNA binding complexes are a critical factor for regulating the selectivity of modular adaptors with the same protein tag to a given substrate in a defined DNA sequence. At the same $k_{\text {cov }}$ of the protein tag module, the lower $K_{\mathrm{D}}$ of the sequence specific DNA-binding complex provides a higher rate constant for the matched pair $\left(k_{\text {app }}\right)$ and the higher $K_{\mathrm{D}}$ for the unmatched complex results in a lower rate constant for the unmatched pair $\left(k_{\text {app }}^{\prime}\right)$ for the sequenceselective modular adaptors. Based on the simulation of the kinetic scheme in Fig. $1 \mathrm{~b}$ (Fig. $\mathrm{S} 1 \dagger$ ), the cross-linking reaction is expected to be orthogonal when the ratio of rate constants $\left(k_{\text {app }} / k_{\text {app }}^{\prime}\right)$ is larger than 100 . The zinc finger proteins used in this study, zif268 and AZP4, showed a nearly two orders of magnitude difference in $K_{\mathrm{D}}$ for complexes with matched and unmatched DNA sequences (Table S2 $\dagger$ ). In fact, modular adaptors with CLIP-tag and BC, developed in this study as the optimized protein tag and substrate pair for achieving $k_{\text {cov }} \ll$ $k_{\text {off }}$, showed an orthogonality of $k_{\text {app }} / k_{\text {app }}^{\prime}>100$ while retaining their reactivities. The GCN4 derived homodimeric modular adaptor, CLIP-G, also revealed orthogonality to ZF-CLIP and AZCLIP.

Sequence specificity of the DNA binding protein has been shown to improve in the presence of a high concentration of $\mathrm{NaCl}$, as nonspecific electrostatic interactions between the protein and DNA decreases with increasing salt concentration. ${ }^{26,27}$ Although the affinity of proteins for the target DNA sequence is also reduced in high concentrations of $\mathrm{NaCl}$, selectivity between the target and non-target DNA is enhanced. Indeed, the $K_{\mathrm{D}}$ in the presence of $200 \mathrm{mM} \mathrm{NaCl}$ was significantly higher for both matched and unmatched complexes (Fig. S6 and Table $\mathrm{S} 4 \dagger$ ), and $k_{\text {app }}$ showed nearly two-fold reduction (Fig. S7 and Table S6 ${ }^{\dagger}$ ), i.e., for the matched combination of ZFCLIP and ODN-ZF-BC: $k_{\text {app }}($ no NaCl $)=7.1 \times 10^{5} \mathrm{M}^{-1} \mathrm{~s}^{-1}$ and $k_{\text {app }}(200 \mathrm{mM} \mathrm{NaCl})=3.1 \times 10^{3} \mathrm{M}^{-1} \mathrm{~s}^{-1}$; for the unmatched combination of ZF-CLIP and ODN-AZ-BC: $k_{\text {app }}^{\prime}(\mathrm{no} \mathrm{NaCl})=5.3 \times$ $10^{3} \mathrm{M}^{-1} \mathrm{~s}^{-1}$ and $\left.k_{\text {app }}^{\prime}(200 \mathrm{mM} \mathrm{NaCl})<10 \mathrm{M}^{-1} \mathrm{~s}^{-1}\right)$. Notably, the reactivity of the protein tag with its substrate was not influenced by the presence of $\mathrm{NaCl}$ (Fig. S10 and Tables S10, S11 $)^{\text {). The }}$ sequence specificity of the crosslinking reaction was further studied in detail by using single or two nucleotide mutated ODN-ZF-BC for ZF-CLIP in the presence of $200 \mathrm{mM} \mathrm{NaCl}$ (Table $\mathrm{S} 7 \dagger)$. A single nucleotide mutation in the consensus sequence of ODN-ZF-BC caused more than one order of magnitude difference in the apparent reaction rate constants (Fig. S9 and Table $\mathrm{S9} \dagger$ ), which was consistent with the difference between the $K_{\mathrm{D}}$ value for the complex of ZF-CLIP with ODN-ZF and that with the mutated sequences (Fig. S8 and Table S8†). These results strongly support our strategy in which the sequence selectivity of the cross-linking reaction by the modular adaptor was governed by $K_{\mathrm{D}}$ under the condition of case 2 of eqn (1) (Fig. 1b). Interestingly, the cross-linking reaction rate of the modular adaptor was drastically accelerated on the DNA origami scaffold compared to the reaction using oligo DNA. In the presence of $200 \mathrm{mM} \mathrm{NaCl}$, AZ-CLIP and ODN-AZ-BC reacted, showing a $k_{\text {app }}$ of $3.1 \times 10^{2} \mathrm{M}^{-1} \mathrm{~s}^{-1}$, which was the slowest combination among the matched pairs of the CLIP-type modular adaptors (Table S6†). AZ-CLIP rapidly reacted with BC in the matched sequence on the DNA origami scaffold while retaining selectivity and showed a $k_{\text {app }}$ of $1.2 \times 10^{4} \mathrm{M}^{-1} \mathrm{~s}^{-1}$, which was nearly two orders of magnitude higher than that for the reaction with ODN-AZ-BC (Fig. S13†). This increase in the stability of the complex between the DNA-binding protein and DNA may arise from the large and negatively charged surface of the DNA origami scaffold surrounding the protein-DNA complex. ${ }^{29}$

\section{Conclusion}

In summary, we have proved a design principle for sequencespecific DNA modifiers driven by specific DNA recognition based on the kinetic parameters for the DNA binding and modification reaction. The kinetic requirements for the complex formation step of DNA and the DNA binder as well as the successive proximity-driven intermolecular chemical reaction were applied to design sequence-selective modular adaptors by using appropriate combinations of a self-ligating protein tag and sequence-specific DNA-binding protein. The modular adaptors with the same self-ligating protein tag bearing different types of sequence-specific DNA-binding proteins indeed reacted with the substrate located in the respective matched DNA sequence, showing low reactivity with substrates in the unmatched sequence. Our design principle is useful for 
expanding the variation of sequence-specific modular adaptors by simply conjugating various types of sequence-specific DNA binding proteins ${ }^{28}$ to the same protein tag that reacts with an appropriate substrate. The resulting orthogonal set of modular adaptors can be used to add a variety of enzymes or receptors to a DNA scaffold to study the chemistry of spatially arranged biomolecules. More importantly, our design principle based on kinetic characteristics of selective modifiers can be applied for designing a wide variety of recognition-driven modifiers targeting not only DNA but also proteins and other biologically relevant molecules.

\section{Experimental procedures}

\section{Materials}

Single-stranded M13mp18, restriction enzymes (NdeI and HindIII), and BC-GLA-NHS (S9237S) were purchased from New England Biolabs (Ipswich, MA, USA). The $p$ CLIP $_{\mathrm{f}}(\mathrm{T} 7)-2$ vector was generously donated by New England Biolabs. Purified oligonucleotides as the staple strands for DNA origami, oligonucleotide primers for gene construction, and all other oligonucleotides were obtained from Sigma-Aldrich (St. Louis, MO, USA), Thermo Fisher Scientific (Waltham, MA, USA), or Gene Design (Osaka, Japan). Escherichia coli BL21 (DE3) competent cells were purchased from Invitrogen (Carlsbad, CA, USA). A Mini Elute gel extraction kit was obtained from QIAGEN (Hilden, Germany). The HiTrap SP XL cation exchange column (5 $\mathrm{mL}$ ), HisTrap HP column ( $5 \mathrm{~mL}$ ), and Sephacryl S-400 were from GE Healthcare (Little Chalfont, UK). PrimeSTAR HS DNA polymerase, T4 DNA ligase, and E. coli DH5 $\alpha$ competent cells were obtained from TaKaRa Bio (Shiga, Japan). Ultrafree-MC-DV was obtained from Merck Millipore (Billerica, MA, USA). A Cosmosil 5C18-MS II column (4.6 i.d. $\times 150 \mathrm{~mm}$ ) and HPLC-grade acetonitrile were purchased from Nacalai Tesque (Kyoto, Japan). Gel electrophoresis-grade acrylamide, bis(acrylamide), phenol, and all other chemicals and reagents were purchased from Wako Chemicals (Osaka, Japan) or Nacalai Tesque. Phosphate buffer (PB) was prepared by mixing $20 \mathrm{mM} \mathrm{Na}_{2} \mathrm{HPO}_{4}$ and $20 \mathrm{mM} \mathrm{NaH} \mathrm{PO}_{4}$.

\section{Preparation of protein-tag derivatives (ZF-SNAP, AZ-SNAP, ZF- CLIP, AZ-CLIP, and CLIP-G)}

Overexpression and purification of ZF-SNAP, AZ-SNAP, and AZCLIP were described in a previous report. ${ }^{\mathbf{1 4 , 1 5}} \mathrm{ZF}$-CLIP and CLIP$\mathrm{G}$ were newly designed in this study. As a typical example, the preparation of ZF-CLIP is shown below. All vectors encoding protein tag derivatives (pET-30a-ZF-CLIP, pET-30a-CLIP-G) were prepared and the protein tag derivatives (ZF-CLIP and CLIP-G) were overexpressed and purified in the same manner.

\section{Construction of vectors for ZF-CLIP (pET-30a-ZF-CLIP)}

CLIP-tag in the pCLIP-tag (T7)-2 vector was amplified by PCR using the following primer pairs.

Forward primer (F_EcoRI_CLIP):

5'-TAATAAGAATTCGGCGGCTCCGGCGGCTCCGACAAAGATTGCGAAA- $3^{\prime}$
Reverse primer (R_CLIP_HindIII):

5'-TTATTAAAGCTTTTAATGATGGTGATGATGATGGTGATGATGGTGGGTACCATTAACCTCGAGCCCGGGG-3'

The PCR products were separated on 1\% agarose gel (TAE) and purified with a Mini Elute gel extraction kit. The PCR products and pET-30a-cys-zif268 were digested with EcoRI and HindIII and were purified in the same manner. These products were incubated with T4-DNA-ligase. The mixture was transferred into $E$. coli $\mathrm{DH} 5 \alpha$ competent cells for amplification. The vector encoding ZF-CLIP (named pET-30a-ZF-CLIP) was purified, sequenced, and transferred into $E$. coli BL21(DE3) competent cells.

\section{Overexpression and purification of ZF-CLIP}

The transformed cells were grown at $37{ }^{\circ} \mathrm{C}$ until the $\mathrm{OD}_{600}$ reached 0.5 , and protein expression was induced with $1 \mathrm{mM}$ IPTG for $24 \mathrm{~h}$ at $25{ }^{\circ} \mathrm{C}$. The soluble fraction of the cell lysate containing the recombinant protein was loaded onto a HisTrap HP column equilibrated with $50 \mathrm{mM}$ phosphate buffer $(\mathrm{pH} 8.0)$ containing $200 \mathrm{mM} \mathrm{NaCl}$ and $1 \mathrm{mM}$ DTT and then eluted over an imidazole gradient. The main fractions containing the target protein were collected, loaded onto a HiTrap SP HP column equilibrated with $50 \mathrm{mM}$ phosphate buffer $(\mathrm{pH}$ 7.0) containing $1 \mathrm{mM}$ DTT, and then eluted over an $\mathrm{NaCl}$ gradient. The purified protein was dialyzed by using $50 \mathrm{mM}$ phosphate buffer $(\mathrm{pH} 8.0)$ containing $1 \mathrm{mM}$ DTT, $50 \mu \mathrm{M} \mathrm{ZnCl}$, and $50 \%$ glycerol and stored at $-20{ }^{\circ} \mathrm{C}$. The purity of the target protein was checked by SDS-PAGE. The major band on the gel corresponded to the calculated molecular weight with an estimated purity of over 95\% (Fig. S15 $\dagger$ ). The modular adaptors were characterized by MALDI-TOF mass spectrometry (AXIMA-LNR, SA matrix, Shimadzu, Kyoto, Japan). ZF-CLIP: $\mathrm{m} / \mathrm{z}$ calcd 32462 , observed 32 440; CLIP-G: $m / z$ calcd 27 108, observed 27 083. Amino acid sequences and calculated molecular weights of the recombinant proteins used in this study are shown in Table S15. $\dagger$

\section{Preparation of substrate-modified ODNs and Alexa 488 modified ODNs}

A coupling reaction between amino-modified ODNs $(100 \mu \mathrm{M})$ and Alexa Fluor 488 NHS ester or succinimidyl derivative of protein tag substrates $(1 \mathrm{mM})$ was carried out in $100 \mathrm{mM}$ phosphate buffer ( $\mathrm{pH}$ 8.0) for $8 \mathrm{~h}$ at ambient temperature. The modified ODNs were purified by reversed-phase HPLC on a Cosmosil 5C18-MS II column $(4.6 \times 150 \mathrm{~mm}$, eluted with $100 \mathrm{mM}$ triethylammonium acetate buffer, $\mathrm{pH}$ 7.0, with a linear gradient over $30 \mathrm{~min}$ from $2.5 \%$ to $30 \%$ acetonitrile at flow rate of $1.0 \mathrm{~mL} \mathrm{~min}^{-1}$ ) and characterized by MALDI-TOF mass spectrometry (AXIMA-LNR, Shimadzu, HPA matrix). A488-ODN-ZF: $\mathrm{m} / \mathrm{z}$ calcd 11 397, observed 11 395; A488-ODN-AZ: $\mathrm{m} / \mathrm{z}$ calcd 11 400, observed 11 399; A488-ODN-AP: $\mathrm{m} / \mathrm{z}$ calcd 12011 , observed 12014 . ODN-AP-2BC: $\mathrm{m} / \mathrm{z}$ calcd 12290 , observed 12 290, ODN-8G-AP-2BC: $m / z$ calcd 21577 , observed 21 578, ODN-11G-ZF-BC: $\mathrm{m} / \mathrm{z}$ calcd 21 160, observed 21 167, ODN-ZFBC: $m / z$ calcd 14 287, observed 14 287, ODN-ZF(G/T)-BC: $m / z$ calcd 14286 , observed 14289 , ODN-ZF(G/C)-BC: $\mathrm{m} / z$ calcd 14 287, observed 14 282, ODN-ZF(GG/TC)-BC: $\mathrm{m} / z$ calcd 14 286, 
observed 14 288, and ODN-ZF(GG/TC)-BC: $\mathrm{m} / \mathrm{z}$ calcd 14 286, observed 14 291. The method for preparing ODN-AZ-BC, ODNAZ-BG, and ODN-24D-AZ-BC was described in a previous report. ${ }^{15}$

\section{Preparation of ${ }^{32} \mathrm{P}$-end-labeled ODNs and analyses of covalent- linkage formation between ${ }^{32} \mathrm{P}$-end-labeled ODNs and modular adaptors}

The ODNs were $5^{\prime}-{ }^{32}$ P-end-labeled as previously described. ${ }^{13 b}$ In a typical experiment for kinetic analysis, ${ }^{32} \mathrm{P}-\mathrm{ODN}-\mathrm{ZF}-\mathrm{BC}$ (less than $0.5 \mathrm{nM}$ ) was incubated with ZF-CLIP (10 nM) in a buffer (pH 8.0) containing $40 \mathrm{mM}$ Tris- $\mathrm{HCl}, 20 \mathrm{mM}$ acetic acid, $12.5 \mathrm{mM} \mathrm{MgCl}_{2}, 1 \mathrm{mM}$ DTT, $1 \mu \mathrm{M} \mathrm{ZnCl}, 0.02 \%$ Tween 20, $200 \mathrm{nM}$ BSA, and $100 \mathrm{nM}$ calf thymus DNA, with or without $200 \mathrm{mM} \mathrm{NaCl}$ at ambient temperature. Aliquots were collected at defined reaction times and quenched by adding SDS and formamide. The aliquots were analysed by $8 \mathrm{M}$ urea PAGE and the intensities of mobility-shifted bands on the gel were analysed with a Storm 860 molecular imager (Amersham plc, Amersham, UK). The kinetics data were fitted to a reaction model assuming first-order kinetics (eqn (1)), and then the second-order rate constants $\left(k_{\text {app }}\right.$ and $k_{\text {app }}^{\prime}$ ) were obtained by dividing the determined first-order rate constants by the concentration of modular adaptors.

$$
Y=1-e^{-k t}
$$

$Y, k$ and $t$ represent the fraction of the cross-linked product, pseudo-first-order rate constant and reaction time, respectively.

To evaluate orthogonality, each $5^{\prime}-{ }^{32}$ P-end-labeled ODN (ODN-ZF-BC, ODN-AZ-BC and ODN-AP-2BC) was incubated with a modular adaptor (10 or $100 \mathrm{nM}$ ) in a buffer ( $\mathrm{pH} 8.0$ ) containing $40 \mathrm{mM}$ Tris- $\mathrm{HCl}, 20 \mathrm{mM}$ acetic acid, $12.5 \mathrm{mM} \mathrm{MgCl}_{2}$, $1 \mathrm{mM}$ DTT, $1 \mu \mathrm{M} \mathrm{ZnCl}$, 0.02\% Tween 20, $200 \mathrm{nM}$ BSA, and $100 \mathrm{nM}$ calf thymus DNA, with or without $200 \mathrm{mM} \mathrm{NaCl}$ at ambient temperature.

\section{Preparation of the DNA origami scaffold with three cavities}

A solution $(50 \mu \mathrm{L})$ containing M13mp18 single-stranded DNA (New England Biolabs, $10 \mathrm{nM}$ ) and staple DNA strands (5 equiv., $50 \mathrm{nM}$, nucleotide sequences of all staple DNA strands are described in our previous report ${ }^{18}$ and Table S13 $\dagger$ ) in buffer (40 mM Tris-HCl, $20 \mathrm{mM}$ acetic acid, $12.5 \mathrm{mM} \mathrm{MgCl}_{2}, \mathrm{pH}$ 8.0) was heated at $95^{\circ} \mathrm{C}$ for $1 \mathrm{~min}$, annealed at $53{ }^{\circ} \mathrm{C}$ for $30 \mathrm{~min}$, and held at $4{ }^{\circ} \mathrm{C}$ in a thermal cycler. The samples were purified by size-exclusion chromatography $(400 \mu \mathrm{L}$ volume of Sephacryl S400, GE Healthcare) equilibrated with a buffer ( $\mathrm{pH} 8.0$ ) containing $40 \mathrm{mM}$ Tris- $\mathrm{HCl}, 20 \mathrm{mM}$ acetic acid, and $12.5 \mathrm{mM}$ $\mathrm{MgCl}_{2}$ in Ultrafree-MC-DV (Millipore).

\section{Preparation of the DNA origami scaffold assembled with modular adaptors}

A DNA origami scaffold was incubated with ZF-CLIP, AZ-CLIP, and/or CLIP-G under the conditions given in the captions of the figures or tables. For example, the cross-linking reaction of each of modular adaptor was carried out for $30 \mathrm{~min}$ at ambient temperature with $5 \mathrm{nM}$ DNA scaffold and $250 \mathrm{nM}$ modular adaptor (ZF-CLIP, AZ-CLIP, or CLIP-G) in buffer ( $\mathrm{pH}$ 8.0) containing $40 \mathrm{mM}$ Tris- $\mathrm{HCl}, 20 \mathrm{mM}$ acetic acid, $12.5 \mathrm{mM} \mathrm{MgCl}_{2}$, $1 \mathrm{mM}$ DTT, $1 \mu \mathrm{M} \mathrm{ZnCl}_{2}, 200 \mathrm{mM} \mathrm{NaCl}$, and $0.02 \%$ Tween 20 . The mixture was purified by size-exclusion chromatography (400 $\mu \mathrm{L}$ volume of Sephacryl S-400 in Ultrafree-MC-DV) equilibrated with the buffer used for the reaction to remove unbound modular adaptors. The fractions containing DNA origami scaffolds were utilized for AFM analyses.

\section{AFM imaging and statistical analysis}

The sample was deposited on a freshly cleaved mica $(1.5 \mathrm{~mm}$ diameter) surface and adsorbed for $5 \mathrm{~min}$ at ambient temperature, followed by three washes with a buffer ( $\mathrm{pH}$ 8.0) containing $40 \mathrm{mM}$ Tris- $\mathrm{HCl}, 20 \mathrm{mM}$ acetic acid, and $12.5 \mathrm{mM} \mathrm{MgCl}_{2}$. The sample was scanned in tapping mode using a fast-scanning AFM system (Nano Live Vision, RIBM Co., Ltd., Tsukuba, Japan) with a silicon nitride cantilever (Olympus BL-AC10DS-A2, Tokyo, Japan). At least three independent preparations of each sample were analyzed by AFM and several images were acquired from different regions of the mica surface. The total number of DNA scaffolds corresponds to the number of expected rectangular shapes possessing three cavities observed by AFM. Specific and nonspecific binding of modular adaptors was counted for only the modular adaptor bound to the perfectly folded DNA scaffold. The yield of the DNA-scaffold-assembled modular adaptor was calculated as described previously ${ }^{\mathbf{1 4 , 1 8}}$ and the results are shown in Table S14. $\dagger$

\section{Fluorescence polarization spectroscopy}

A fluorescence polarization assay by using an Infinite 200 PRO F Plex (Tecan, Männedorf, Switzerland) was conducted to determine the equilibrium dissociation constant $\left(K_{\mathrm{D}}\right)$ (Fig. S4, S6 and $\mathrm{S} 8 \dagger)$ and kinetic parameter $\left(k_{\mathrm{on}}\right.$ and $\left.k_{\mathrm{off}}\right)$ (Fig. S11 $\dagger$ ) for the complexes of the modular adaptor with a fluorophore-modified ODN. The rate constant of covalent bond formation of the protein tag derivatives and fluorophore-modified substrates was also determined (Fig. S10 $\dagger$ ). The kinetic parameter $k_{\text {obs }}\left(\mathrm{s}^{-1}\right)$ was fitted to the reaction model assuming first-order kinetics, and then the second-order rate constants of the process were determined. These assays were carried out in a buffer $(\mathrm{pH} 8.0)$ containing $40 \mathrm{mM}$ Tris- $\mathrm{HCl}, 20 \mathrm{mM}$ acetic acid, $12.5 \mathrm{mM}$ $\mathrm{MgCl}_{2}, 1 \mathrm{mM}$ DTT, $1 \mu \mathrm{M} \mathrm{ZnCl}_{2}, 100 \mathrm{nM}$ calf thymus DNA, and $0.02 \%$ Tween 20 at $25{ }^{\circ} \mathrm{C}$ with or without $200 \mathrm{mM} \mathrm{NaCl}$.

\section{Conflicts of interest}

The authors have no conflicts of interest directly relevant to the content of this article.

\section{Acknowledgements}

This work was supported in part by Grants-in-Aid for Scientific Research from the Ministry of Education, Culture, Sports, Science and Technology, Japan, to E. N. (Nos. 15 H05492 and 
17H05440) and T. M. (Nos. 15H01402 and 17H01213) and by JST CREST Grant Number JPMJCR18H5 (T.M.).

\section{Notes and references}

1 (a) T. A. Baillie, Angew. Chem., Int. Ed., 2016, 55, 13408; (b) J. Singh, R. C. Petter, T. A. Baillie and A. Whitty, Nat. Rev. Drug Discovery, 2011, 10, 307; (c) T. L. Foley and M. D. Burkart, Curr. Opin. Chem. Biol., 2007, 11, 12; (d) M. A. Warpehoski and L. H. Hurley, Chem. Res. Toxicol., 1988, 1, 315; (e) W. C. Tse and D. L. Boger, Chem. Biol., 2004, 11, 1607.

2 (a) A. Ali and S. Bhattacharya, Bioorg. Med. Chem., 2014, 22, 4506; (b) S. Neidle, Nat. Prod. Rep., 2001, 18, 291.

3 T. Bando and H. Sugiyama, Acc. Chem. Res., 2006, 39, 935.

4 R. T. Kovacic, J. T. Welch and S. J. Franklin, J. Am. Chem. Soc., 2003, 125, 6656.

5 D. D. F. Ma, T. Rede, N. A. Naqvi and P. D. Cook, Biotechnol. Annu. Rev., 2000, 5, 15.

6 N. C. Seeman and H. F. Sleiman, Nat. Rev. Mater., 2017, 3, 17068.

7 P. W. K. Rothemund, Nature, 2006, 440, 297.

8 (a) F. Hong, F. Zhang, Y. Liu and H. Yan, Chem. Rev., 2017, 117, 12584; (b) M. Madsen and K. V. Gothelf, Chem. Rev., 2019, 119, 6384.

9 (a) A. R. Chandrasekaran, N. Anderson, M. Kizer, K. Halvorsen and X. Wang, ChemBioChem, 2016, 17, 1081; (b) V. Linko, S. Nummelin, L. Aarnos, K. Tapio, J. Toppari and M. Kostiainen, Nanomaterials, 2016, 6, 139; (c) A. Rajendran, E. Nakata, S. Nakano and T. Morii, ChemBioChem, 2017, 18, 696.

10 (a) C. M. Niemeyer, Angew. Chem., Int. Ed., 2010, 49, 1200; (b) B. Sacca' and C. M. Niemeyer, Chem. Soc. Rev., 2011, 40, 5910; (c) Y. R. Yang, Y. Liu and H. Yan, Bioconjugate Chem., 2015, 26, 1381; (d) J. B. Trads, T. Tørring and K. V. Gothelf, Acc. Chem. Res., 2017, 50, 1367.

11 (a) O. I. Wilner, Y. Weizmann, R. Gill, O. Lioubashevski, R. Freeman and I. Willner, Nat. Nanotechnol., 2009, 4, 249; (b) J. Fu, M. Liu, Y. Liu, N. W. Woodbury and H. Yan, J. Am. Chem. Soc., 2012, 134, 5516; (c) J. Fu, Y. R. Yang, A. Johnson-Buck, M. Liu, Y. Liu, N. G. Walter, N. W. Woodbury and H. Yan, Nat. Nanotechnol., 2014, 9, 531; (d) C. B. Rosen, A. L. B. Kodal, J. S. Nielsen, D. H. Schaffert, C. Scavenius, A. H. Okholm, N. V. Voigt, J. J. Enghild, J. Kjems, T. Tørring and K. V. Gothelf, Nat. Chem., 2014, 6, 804.

12 J. Fu, Y. R. Yang, S. Dhakal, Z. Zhao, M. Liu, T. Zhang, N. G. Walter and H. Yan, Nat. Protoc., 2016, 11, 2243.

13 (a) B. Saccà, R. Meyer, M. Erkelenz, K. Kiko, A. Arndt, H. Schroeder, K. S. Rabe and C. M. Niemeyer, Angew. Chem., Int. Ed., 2010, 49, 9378; (b) E. Nakata, F. F. Liew, C. Uwatoko, S. Kiyonaka, Y. Mori, Y. Katsuda, M. Endo, H. Sugiyama and T. Morii, Angew. Chem., Int. Ed., 2012, 51, 2421; (c) T. A. Ngo, E. Nakata, M. Saimura, T. Kodaki and T. Morii, Methods, 2014, 67, 142; (d) K. J. Koßmann, C. Ziegler, A. Angelin, R. Meyer, M. Skoupi, K. S. Rabe and C. M. Niemeyer, ChemBioChem, 2016, 17, 1102; (e)
S. Sagredo, T. Pirzer, R. A. Aghebat, M. A. Goetzfried, G. Moncalian, F. C. Simmel and F. De La Cruz, Angew. Chem., Int. Ed., 2016, 55, 4348; (f) K. N. Lovendahl, A. N. Hayward and W. R. Gordon, J. Am. Chem. Soc., 2017, 139, 7030; $(g)$ T. Kurokawa, S. Kiyonaka, E. Nakata, M. Endo, S. Koyama, E. Mori, N. H. Tran, H. Dinh, Y. Suzuki, K. Hidaka, M. Kawata, C. Sato, H. Sugiyama, T. Morii and Y. Mori, Angew. Chem., Int. Ed., 2018, 57, 2586. 14 E. Nakata, H. Dinh, T. A. Ngo, M. Saimura and T. Morii, Chem. Commun., 2015, 51, 1016.

15 T. M. Nguyen, E. Nakata, M. Saimura, H. Dinh and T. Morii, J. Am. Chem. Soc., 2017, 139, 8487.

16 N. P. Pavletich and C. O. Pabo, Science, 1991, 252, 809.

17 A. Keppler, S. Gendreizig, T. Gronemeyer, H. Pick, H. Vogel and K. Johnsson, Nat. Biotechnol., 2003, 21, 86.

18 T. A. Ngo, E. Nakata, M. Saimura and T. Morii, J. Am. Chem. Soc., 2016, 138, 3012.

19 T. Sera and C. Uranga, Biochemistry, 2002, 41, 7074.

20 A. Gautier, A. Juillerat, C. Heinis, I. R. Corrêa Jr, M. Kinder mann, F. Beaufils and K. Johnsson, Chem. Biol., 2008, 15, 128.

21 (a) G. V. Los, L. P. Encell, M. G. McDougall, D. D. Hartzell, N. Karassina, C. Zimprich, M. G. Wood, R. Learish, R. F. Ohana, M. Urh, D. Simpson, J. Mendez, K. Zimmerman, P. Otto, G. Vidugiris, J. Zhu, A. Darzins, D. H. Klaubert, R. F. Bulleit and K. V. Wood, ACS Chem. Biol., 2008, 3, 373; (b) C. G. England, H. Luo and W. Cai, Bioconjugate Chem., 2015, 26, 975.

22 G. Schreiber, G. Haran and H.-X. Zhou, Chem. Rev., 2009, 109, 839.

23 (a) F. C. Collins and G. E. Kimball, J. Colloid Sci., 1949, 4, 425; (b) P. A. Maslak, J. Am. Chem. Soc., 1989, 111, 8201; (c) O. G. Berg and P. H. von Hippel, Annu. Rev. Biophys. Biophys. Chem., 1985, 14, 131; (d) C. Berger, L. Piubelli, U. Haditsch and H. Rudolf Bosshard, FEBS Lett., 1998, 425, 14.

24 (a) P. H. Von Hippel and O. G. Berg, J. Biol. Chem., 1989, 264, 675; (b) J.-S. Kim and C. O. Pabo, Proc. Natl. Acad. Sci. U. S. A., 1998, 95, 2812; (c) M. Geertz, D. Shore and S. J. Maerkl, Proc. Natl. Acad. Sci. U. S. A., 2012, 109, 16540.

25 (a) I. A. Hope, S. Mahadevan and K. Struhl, Nature, 1988, 333, 635; (b) E. K. O'Shea, R. Rutkowski and P. S. Kim, Science, 1989, 243, 538; (c) T. E. Ellenberger, C. J. Brandl, K. Struhl and S. C. Harrison, Cell, 1992, 71, 1223; (d) P. König and T. J. Richmond, J. Mol. Biol., 1993, 233, 139; (e) W. Keller, P. Konig and T. J. Richmond, J. Mol. Biol., 1995, 254, 657.

26 (a) M. T. Record, C. F. Anderson and T. M. Lohman, Q. Rev. Biophys., 1978, 11, 103; (b) D. Jantz and J. M. Berg, Biophys. J., 2010, 98, 852; (c) B. L. Jutras, A. Verma and B. Stevenson, Curr. Protoc. Microbiol., 2012, 24, 1F.1.1; (d) A. Esadze and J. Iwahara, J. Mol. Biol., 2014, 426, 230.

27 (a) P. L. Privalov, A. I. Dragan and C. Crane-robinson, Nucleic Acids Res., 2011, 39, 2483; (b) A. Atzori, S. Liggi, A. Laaksonen, M. Porcu, A. P. Lyubartsev, G. Saba and F. Mocci, Can. J. Chem., 2016, 94, 1181; (c) A. Esadze, C. A. Kemme, A. B. Kolomeisky and J. Iwahara, Nucleic Acids Res., 2014, 42, 7039. 
28 (a) C. O. Pabo and R. T. Sauer, Annu. Rev. Biochem., 1992, 61, 1053; (b) P. Prabakaran, J. G. Siebers, S. Ahmad, M. M. Gromiha, M. G. Singarayan and A. Sarai, Structure, 2006, 14, 1355; (c) R. Gamsjaeger, C. K. Liew, F. E. Loughlin, M. Crossley and J. P. Mackay, Trends Biochem. Sci., 2007, 32, 63; (d) W. H. Hudson and E. A. Ortlund, Nat. Rev. Mol. Cell Biol., 2014, 15, 749.

29 (a) A. G. Cherstvy, Phys. Chem. Chem. Phys., 2011, 13, 9942; (b) R. C. Harris, T. MacKoy, A. C. D. MacHado, D. Xu,
R. Rohs and M. O. Fenley, in RSC Biomolecular Sciences No. 24 Innovations in Biomolecular Modeling and Simulations, ed. T. Schlick, Royal Society of Chemistry, Cambridge, 2012, vol. 2, pp. 53-80; (c) M. Barbi and F. Paillusson, in Advances in Protein Chemistry and Structural Biology, ed. T. Karabencheva-Christova, Elsevier, Netherlands, 2013, vol. 92, pp. 253-297. 